\title{
The Cornelius Ryan Collection of World War II Papers
}

\author{
Doug McCabe
}

My country can never again afford the luxury of another Montgomery success.

BERNARD, The Prince of the Netherlands,

Interview with Cornelius Ryan for the book A Bridge Too Far

The quotation above is just one of thousands of golden nuggets contained in the collection of research files of reporter, journalist and author Cornelius Ryan (1920-1974). This native Irishman was one of the first writers on military subjects to go beyond using official records and the reminiscences of highranking commanders by contacting common soldiers and civilians in order to access their personal experiences of war. Along with his skill as a writer, the anecdotes they provided him with "humanized" his books, made them best sellers and turned two of them into films. And - to prove their longevity-The Longest Day (1959), The Last Battle (1966) and A Bridge Too Far (1974) are still in print while the films are still shown several times a year on American television.

The Ryan Collection, housed at Ohio University in Athens, Ohio, is the most heavily used collection at the Mahn Center for Archives and Special Collections. Queries come in from students and faculty on campus, from researchers throughout the U.S. as well as from overseas, especially Europe. They range from relatives and descendants to casual and amateur historians to professional academicians. They ask for just a few pages from a questionnaire to dozens of pages of documents or photographs. What they all seem to want are the stories that get at the pathos of war and conflict.

This is because the Ryan Collection is one of a few archival collections related to the Second World War to house the memories of ordinary people caught up in unordinary times. Just consider these statistics: 
The longest day

\begin{tabular}{lcccccc}
\hline & American & British & Canadian & French & German & Total \\
\hline People & 748 & 212 & 121 & 20 & 43 & 1144 \\
Questionnaires & 677 & 134 & 108 & 0 & 0 & 969 \\
Interviews & 36 & 64 & 12 & 19 & 41 & 172 \\
Accounts & 12 & 5 & 1 & 0 & 0 & 18 \\
Diaries & 2 & 3 & 0 & 0 & 2 & 7
\end{tabular}

Plus 10o Photographs

The last battle

\begin{tabular}{|c|c|c|c|c|c|c|c|}
\hline & American & British & French & $\begin{array}{l}\text { Ger. } \\
\text { Civilian }\end{array}$ & $\begin{array}{l}\text { Ger. } \\
\text { Military }\end{array}$ & Russian & Total \\
\hline People & 280 & 75 & 11 & $15^{8}$ & 131 & 35 & 690 \\
\hline Questionnaires & $25^{6}$ & 33 & 6 & 64 & 56 & $\mathrm{O}$ & 415 \\
\hline Interviews & 83 & 34 & 8 & 143 & 91 & 28 & 387 \\
\hline Accounts & $\mathrm{o}$ & 11 & $\mathrm{o}$ & 10 & 14 & 9 & 44 \\
\hline Diaries & 2 & 4 & 2 & 12 & 6 & o & 26 \\
\hline
\end{tabular}

Plus 838 Photographs

A bridge too far

American British Canadian Dutch Dutch German Polish Total

\begin{tabular}{lrrrrrrrr} 
& \multicolumn{7}{c}{ Civ. } & Mil. \\
\hline People & $45^{2}$ & 426 & 1 & 271 & 14 & 66 & 12 & 1242 \\
Questionn & 417 & 422 & 1 & 250 & 14 & 52 & 11 & 1167 \\
Interviews & 69 & 142 & 0 & 130 & 7 & 40 & 8 & 396 \\
Accounts & 12 & 13 & 0 & 17 & 1 & 3 & 0 & 46 \\
Diaries & 2 & 17 & 0 & 24 & 1 & 4 & 0 & 48
\end{tabular}

Plus 981 Photographs

As these figures show, for the three books Ryan had some kind of contact with over 3,000 people and he gathered just under 2,000 photographs. Plus, there are dozens of maps, copies of official documents, manuscripts, correspondence, screenplays, scrapbooks and articles. In addition, there are files containing materials from Ryan's entire career as a war correspondent, 
reporter, journalist, editor, and book reviewer, and even memorabilia such as a piece of Hitler's urinal and Hideki Tojo's (Japanese general and Prime Minister) cigarette case.

The Ryan Collection is arranged as Ryan had the materials filed in his home office: first, the folders related to his three Second World War battle books: second, supplementary correspondence related to other works; and third, scrapbooks and memorabilia. The book folders are arranged in the following order: by general or overarching materials, by nationality, by military unit or civilian location, and by individuals. While in the files pertaining to The Longest Day military units are simply arranged by divisions or even broader categories, for $A$ Bridge Too Far the military files on individuals are set at the regimental level and the civilian folders are arranged by city, town or village locations.

The "people" folders are the unique gold mine of the Collection: they may contain questionnaires, interview transcripts, accounts, diaries and, on occasion, photographs, drawings and maps. The questionnaires pose standard queries such as name, rank, military unit, current employment and residence. They then expand into questions about when the person learned of the operation, what his reaction was, what entering combat was like, what rumors were heard; other questions pertained to the loss of friends, the conversations with colleagues, the number of wounded, the experience of being captured and what that was like, or to any heroic, memorable, or stupid events, and contacts with others, be they military or civilian, or enemies.

Many of the stories Ryan collected from these people he could not use or the books would have been unwieldly. But regardless of whether these stories were only partially used or not used at all, these are the undiscovered nuggets current and future researchers can use — and have been using — to add luster to their own work. Here is just one example: First Lieutenant Robert Riekse wrote to Ryan that he was an aide to the U.s. 1st Infantry Division's Assistant Commanding General Willard Wyman when they landed on Omaha Beach on D-Day. Riekse filled out the questionnaire with the usual information. But it was the extra items he sent that turned out to be extraordinary. First were the four Message forms, all written on the beach the morning of June 6th. Two are most poignant: "Arrived on beach at H+110. Situation difficult. Information limited. Progress slow." And "Request wave $\mathrm{H}+215$ be sent at once." These are typical clipped military statements, but they indicate how desperate events were that morning. Next in the file is a business envelope containing a strip of $35 \mathrm{~mm}$ negatives. These turned out to be an amazing surprise. First, there are four photos of an extension ladder mounted to a DUKW topped with machineguns. These are possibly the only images that exist or 
have survived of the four vehicles intended to be off Pointe du Hoc to provide suppression fire while the U.s. Rangers scaled the cliffs. Second (and these are perhaps the real coup) are two images, taken on Omaha that morning, that were unknown and unpublished for 5 o years. Making these photos extra special is the story of the official photographer who landed on the same beach, Robert Capa. Of the 105 images he took only eight survived a darkroom disaster. Now there are ten. Those photos were first published in D-Day: Then and Now (London: After the Battle) in 1995. We will never know why Ryan did not use the materials in his book, The Longest Day. But, the discovery points out that new information and new interpretations can be found hidden away in archives.

To understand how the Ryan Collection came to assume its present shape and nature, it may be illuminating to revisit his life story and recall his experiences as a soldier and a journalist. Cornelius J. Ryan was born in Dublin, Ireland on June 5,1920 . He was educated at the Synge Street Christian Brothers School, just across the road from his house, and studied violin at the Irish Academy of Music. He worked for a brief period at an insurance agency in Dublin and was one of the first employees of Aer Lingus, doing almost everything but fly the plane. At the age of nineteen he moved to London and entered the employ of Garfield Weston, the grocery magnate and Member of Parliament, while taking a night job as an office boy with Reuters. During the Battle of Britain and the Blitz, Ryan helped Weston supply food to Londoners sheltering in the Underground. By the fall of 1941 he was helping feed nearly 30,0oo people in the shelters. From that work he shifted briefly to the British Ministry of Information's film unit for a stint of writing scripts as well as producing and directing documentaries.

By late 1941 he joined the staff of the London Daily Telegraph and on his own slipped into neutral Ireland to get a scoop on that country's non-neutral collaboration with the Nazis. He was found out by the authorities, beaten and thrown out of the country for his troubles. He was then assigned to cover the U.s. 8th and 9th Air Forces with which he flew 14 bombing missions (being hit twice by shrapnel) in 1943 and 1944. By August of 1944 Ryan was assigned to cover General George Patton's Third Army, an assignment which enabled him to witness the ground war, the Allied breakout dash from St. Lo, the battles at the Mortain Gap, Coutance and Avranshes, the German surrender of Le Mont St. Michel, and subsequently the liberation of Paris, the battles at Metz, Nancy, the Lorraine-Pallatine Campaign and the trial of the Battle of the Bulge (an anecdote of his experience there was noted in John Eisenhower's The Bitter Woods: The Battle of the Bulge), and the end of the European war in Czechoslovakia. 
After the Nazi surrender in early May of 1945 and a month-long visit with his family in Ireland, he headed out to the Far East to cover the final phase of the Pacific war. Upon the occupation of Japan by American forces he opened a Tokyo bureau for the Telegraph and also served as a stringer for Time. While in Japan, he witnessed the fiasco of the arrest for war crimes and attempted suicide of General Tojo. He left Japan in 1946, but not before covering the atomic bomb test at Bikini Island and co-writing his first book, Star-Spangled Mikado.

His next stop was Palestine, still working for the Telegraph and Time/Life. In 1947, while bouncing between London, Paris and New York between assignments to study photography, Ryan was asked to take a position on the international staff of Time/Life. No fool, he took the job, moved to the U.S. and was immediately sent to the Dominican Republic where he wrote an exposé on dictator Trujillo called "Beautiful Murder." Disagreeing with Luce's editorial policies, he left Time/Life in late 1949 to join Newsweek's special projects department. Here he produced an innovative weekly news show in the early days of television. The program only lasted into the next year, but Ryan also used that time to become a naturalized U.s. citizen in 1950, marry Kathryn Morgan that same year, write a book on the life of Douglas MacArthur and write several items for Collier's magazine.

Those pieces quickly turned into a six-year stint with the magazine, during which he wrote around 50 articles and handled all the special projects. The latter included a series on space exploration featuring the ideas of Werner von Braun and predating the actual space program by ten years. Ryan also parlayed that series into two books, Across the Space Frontier and Conquest of the Moon. By 1956 he had made it to Senior Writer at Collier's and produced two award winning articles, "Five Desperate Hours in Cabin 56," about the sinking of the Andrea Doria, and "One Minute to Ditch," about the ditching of a Pan Am passenger plane in the Pacific Ocean, which graced the cover of the final issue of the magazine.

With the demise of Collier's, Ryan was left to do freelance work for television and magazines. Yet he had time and a special arrangement with the Reader's Digest magazine to get serious about a book he had had in mind since 1949-The Longest Day. Having witnessed the awe inspiring invasion from the air on a bombing mission and from the sea off омAнA Beach on June 6th 1944, and having revisited and written on the scenes of Normandy five years after D-Day, Ryan was struck that no one had really explored the human side of the story.

He began as any researcher would by reviewing all he could of official documents, books and articles. Then, he did what was nearly unheard of in the late 1950s. He placed notices in magazines, newspapers, journals and 
newsletters soliciting contacts with veterans of all nationalities who participated in D-Day. In the meantime he made a deal with Reader's Digest: they would provide Ryan with assistants and translators as well as office space in New York, Ottawa, London, Paris and Bonn, and in return they would publish a serialized version of the book prior to the release of the hardback by Simon and Schuster. (This arrangement worked so well it was used for Ryan's next two books.) The Longest Day, released in 1959, was an immediate best seller and went on to be released in numerous editions in over 30 languages, selling well over 30 million copies.

Belgian film producer Raoul Levy purchased the film rights to the book, but unable to come up with the financing, he sold the rights to producer and director Darryl F. Zanuck, self-exiled to France and looking for a comeback. Zanuck hired Ryan to write the screenplay. Ryan, however, held Zanuck off until after the 1960 election, while he finished up working for the John F. Kennedy residential campaign and witnessed the election night returns from the Kennedy family compound in Hyannis Port, MA. Finally, Ryan packed up the family and his research files and went to Paris to write the screenplay. The relationship between the two men was rocky or, as Zanuck's assistant Elmo Williams noted, "it was hate at first sight." The crux of the conflict was that Ryan wanted the film to reflect the facts of D-Day whereas Zanuck had no problem taking literary or "Hollywood" license. The bitterness between the two men was mostly kept out of the public eye, but privately Ryan referred to Zanuck as "... one of the last of the great vulgarians" (letter from Ryan to Maj. Gen. R K Belchem, dated June 18, 1969).

Ryan intended to follow up The Longest Day with books on several topics, but especially on Operation Market Garden. With the help of the new President Kennedy, however, he arranged for a research trip to Russia, wherewith Soviet military expert John Ericson (formerly of MI6) - they were the first post-war journalist and historian to have a crack at the Moscow archives and interviews with Russian veterans. It was on this trip that the Russians finally "officially" admitted they knew all along Hitler had committed suicide in his bunker in Berlin. (Ryan had a personal interview with Kennedy and was debriefed by the CIA regarding this trip.) Using this coup and his many interviews and questionnaires with veterans and civilians, Ryan produced his second book on the war, The Last Battle. This book broadly covered the last month of the war in northwest Europe while focusing particularly on the capture of Berlin by the Russians. Published in 1966, The Last Battle quickly hit the bestseller list. He was hired to write a screenplay for that book as well as Leon Uris' Armageddon. Unfortunately, the projects fell through.

Ryan returned to the Market Garden project and by the winter of 1970 had nearly all his research completed when he had a series of illnesses. In July of 
1970, Ryan learned he had cancer and spent considerable time and research learning about the best treatments and doctors, postponing by nearly two and a half years work on his next book, $A$ Bridge Too Far.

Shortly after his cancer news he began secretly taping the events in his life, the fight with the cancer, the work on the book and family matters, which he labeled "Cancer Tapes." At the same time his wife Kathryn began a diary chronicling the same events. Upon Cornelius' death she found the tapes and, combined with her diary she composed the book, A Private Battle, which was released in 1979 with the pair of them as authors. The book was made into a made-for-TV movie the following year.

By late 1972, with his cancer in remission but knowing it could return at any time, and with his need to cover his medical bills as well as provide for his family, Ryan concentrated on completing the manuscript of A Bridge Too Far. The book was released on the 3oth anniversary of Operation Market Garden in September of 1974 and was an instant best seller. Ryan went on an extensive and exhausting book tour including a war correspondent reunion in The Netherlands. Unfortunately, his cancer returned with a vengeance and he succumbed to the disease in November. He was 54 years old.

By that time Joseph Levine had already fulfilled his promise to Ryan and went forward with the making of the film based upon the book. It, too, was a hit and is still shown on television in the U.s. and Europe.

After Ryan's death, fifteen repositories vied to house the Collection, but Ohio University won out in 1981. The Collection contains all the research files noted above as well as Ryan's personal library and memorabilia. There is a room dedicated to a permanent display of materials from the Collection detailing the process Ryan used to compose his books, films and articles. The attached Mahn Center reading room serves as a comfortable setting for researchers to work with the Collection. The Center's archivists are well versed in the Collection and can provide assistance to visitors and remote researchers alike. It is also important to note that the Collection is open to all comers, be they amateur or professional historians. ${ }^{1}$

The Mahn Center has several other archival collections pertaining to the Second World War and other conflicts. ${ }^{2}$ They include a written account by Lieutenant J.G. William Culver who was a leader of a U.s. Navy Combat

1 The Cornelius Ryan Collection can be accessed via this url: https://www.library .ohiou.edu/about/collections/archives-special-collections/manuscript-collections/ cornelius-ryan-collection-of-world-war-II-papers/

2 They can be seen at https://www.library.ohiou.edu/about/collections/archives-special -collections/manuscript-collections/military/ 
NIJNEGEN.

Bartels, Willem Frederik Henri. Short interview by telephoné.

Willem Bartels, during the period under survey, was a student who did not work as his University, the Catholic University of Nijmegen, was closed by the Germans. In September, 1944, he was hiding He was arrested by the SD (Sicherheitsdienst, Security Service) during the summer, as being suspected tof belong.to an illegal movement called "Christofoor. "He belonged, in fact, to the Nijmegen IO (Landelijke Organisatie, National Organitation for the aid of peopl, in hiding) which the Germans did not know. He spent some time in cui tody at the Arnhem SD-HQ and was released on August 28 or 29.

He returned to Nijmegen but thought it better not to stay with hi: family, who lived in a large house at van Schaeck Mathonsingel (singel $=$ boulevard) that runs from the station to the Keizer Karel. plein (plein = square) in the heart of the city. Bartels"dived und in a house roughly opposite his parent', some 50 or 60 meters away

Hisffamily consisted of his father Jacobus Franciscus Michiel, a medical doctor, his mother, Josepha Rosalia Marie Bartels nee Payens, and his brother Jaap Maria, then 15 years old and a high school student.

On Tuesday afternoon, September 20, at approximately 18.00 hours Bartels looked from, his hiding place and saw some 150 German soldiers carefully moving toward Keizer Karelplein. Some went from tres to tree, others, via the foxholes that were dug in the narrow park of green belt in the middle of the street.

Suddenly he saw two soldiers, grown-up men and therefore not Hitler Youths, who were carrying on their backs what would be described today as insecticide spraying apparatus. They went from house to house, out a window and then what looked like "spraying something inside." When they were busy with the next houst the one they had just dealt with already started to burn.

To Bartels' horror his house was "treated" also and the first flames became visible not long afterward.

He then ran across the street. The Germans in the meantime were retreating again toward the station, the two fire bugs disappeared in another direction. Somebody scremed something at him in German, but Bartels went on and saw his father, mother and brother emerge from the house, bewildered and frightened, but otherwise all right. They had remembered to take with them some vital things such as ration cards, jewelry and various documents.

All then went away reaching, via back street and gardens, a safe area.

In 1940 a new party was reated in opposition to the N.S.B. It was called "Nederlaridse Unie", i.e. Dutch Uivion. Facty membership numbera in the 100,000's. Yu 1941 it: was banned by the Germans, The leculers of the party starte two underground newspapers: one for Protestant: called "Je maintiendrai" (motto of the Ho ise of Orarge);

FIGURE 1 Ryan interview with a Willem Frederik Henri Bartels, a former student of the Catholic University Nijmegen. The interview with Bartels is undated, circa 1967. 


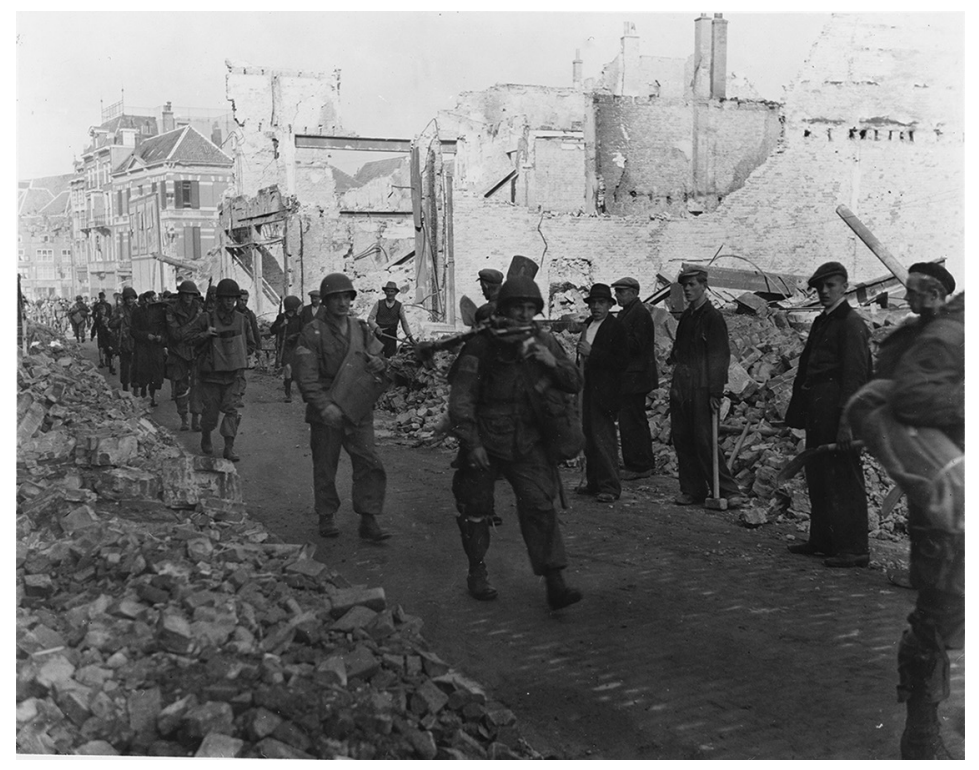

FIGURE 2 US paratroopers returning from the front lines march through the ruins of Nijmegen. ${ }^{3}$

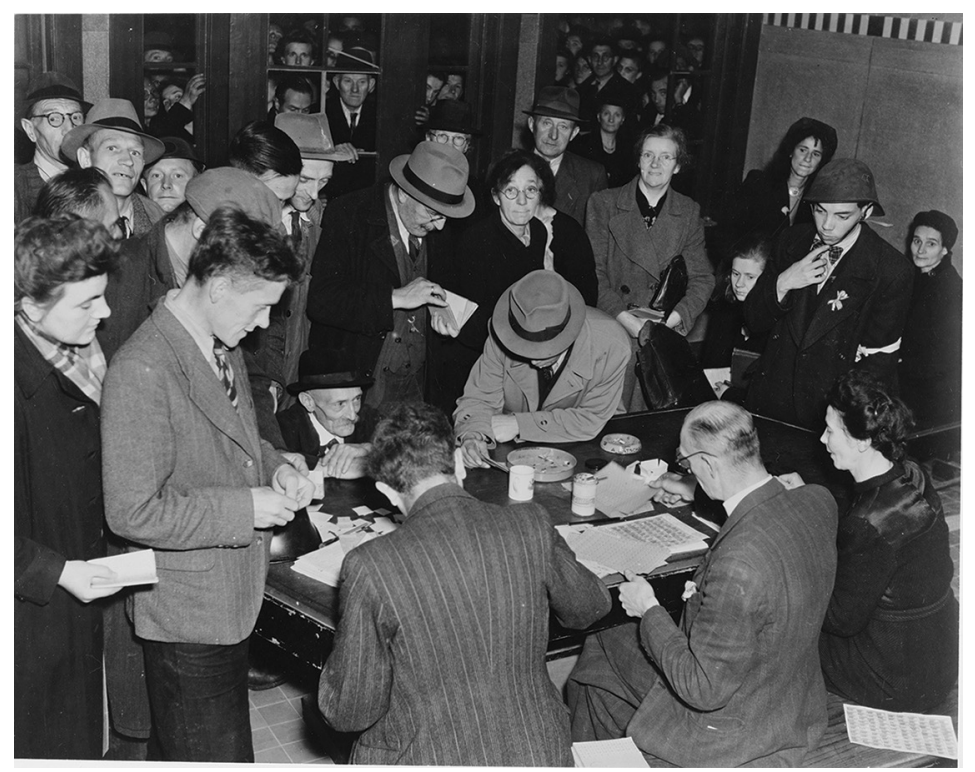

FIGURE 3 Dutch folks waiting to replace ration cards at a public bath house in Nijmegen. RYAN COLLECTION, BOX 146, FOLDER 2.

3 None of the photos have locations or dates or photographer's name. They were taken by one or more United States Signal Corps photographers. 
Demolition group sent in to OMAHA to clear beach obstacles. Interestingly, he noted on a page just inside the cover, "picked up this [blank] book 6-6-44 on beach of Normandy beside a body." Another item is a film called, "Combat Report 12," a U.s. newsreel on Operation Market Garden including footage shot by George Hebenstreit as he parachuted from an airplane on the morning of September 17, 1944.

All photos courtesy of the Cornelius Ryan Collection, Mahn Center, Alden Library, Ohio University, Athens OH USA.

\section{Bibliography}

Eisenhower, John S.D. 1969. The Bitter Woods: The Battle of the Bulge. New York: G. P. Putnam's Sons.

Levine, Joseph E., producer. 1977. A Bridge Too Far (MGM)

Ramsey, Winston G., ed. 1995. D-Day: Then and Now. London: After the Battle.

Ryan, Cornelius and Kelly, Frank. 1947.Star-Spangled Mikado. New York: R. M. McBride. Ryan, Cornelius. 1959. The Longest Day. New York: Simon and Schuster. Ryan, Cornelius. 1966. The Last Battle. New York: Simon and Schuster. Ryan, Cornelius. 1974. A Bridge Too Far. New York: Simon and Schuster. Zanuck, Darryl F., producer. 1962. The Longest Day. 2oth Century Fox. 